細菌学的にみた東京都の原料乳括よび市販乳の品質について

春 田 三佐 夫*

近年一般国民の乳拉よび乳製品汶対する関心がたが るにつれて，これら製品の消費量も漸次增加の傾向をた ぞりつつあることは，国民保健の上から，まこと喜ぶ べき現象といえよう。しかし，一方に扔いて，消費量の 上界に比例して，これら乳扔よび乳製品に起因する中毒 事故の発生例がしばしばみられることは，公衆衛生上等 閑視し得ない問題である.1955年 3 月東京都下の小学校 に爆発発生をみた脱脂粉乳によるブドウ球菌性食中毒例 1),さらにその後 8 月から 9 月にかけて, 関西方面を中 心として発生した育児用調製粉乳飞よる比素中毒例2)の ごときは，事故としては，わが国ではもちろん，外国で もまれな事例で, まだ一般の記憶にもなまなましいとこ ろである。また牛乳を主原料とする食品, たとえばシュ ークリーム，クリームパンなぞによる細菌性食中毒が， 毎年少なくとも 2,3 例はみられるということも，見の がせない事実である。

これらの事実は，一体何を意味するのであろらか．周 知の通り, 乳敃よび乳製品は, 食品衛生法特よび厚生省 令第 52 号，第 54 号なぞによって厳重な取締りを受け，そ の内容についてはもちろん，製造取报いなどの点につい ても, きわめて高度の規定が設けられてはいるが, 乳お よび乳製品は, 他の食品類と異なり, その生産取扱いな ぞの面に和いて，実際上かなり多くの困難な間題を含ん でいるために，実情は必ずしも満足すべき衛生状態にな いということを意味するのである。将来，これら乳拉よ び乳製品による事故を未然に防止し,さらに進んで栄養 的にも, 衛生的にも, 品質のすぐれた製品を国民に供給 し，国民の健康保全に資するためには，原料乳の生産， 製品の製造取扱いなどの面について，種々の角度からな 招一層の検討改善の必要があることを痛感するものであ る.

以上の意味に和いて，最近に拁ける原料乳，あるいは 市販乳の品質について，ここで考えてみることも決して 無駄でないと思う。もっとも, 乳質と一言にいっても, 種々の面について考壳ねばならぬ、たとえば，現にわが 国でとくに問題になっている無脂乳固形分不足の間題 (低蛋白・高脂肪乳), 低酸度二等乳なぞ, 種々の問題 があるが，これらについては，乙ばらく拈き今回は，そ の改善が今日強調されている細菌学的な乳質の点につい て，都衛生局ならびにわれわれが調查した資料などにも とづいて解説を試み, 各位の参考に供したいと思う。

* 東京都立衛生研究所

日獣会誌 11 (1958)

\section{1. 原料乳の乳質}

原料乳の細菌学的検查成績は, 全国的なものについて

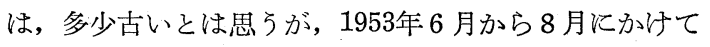
厚生省が各県衛生部の協力によって収集したもの3)があ るので，それについて過去の姿をらりかえってみよう。 その成績（第 1 表）は，現行法規淀められた規格の 1 cc中細菌数 (Breed-個体值) 400 万をこ光るものが $43 \%$ を占めて和り，さらに 1,000 万をこ党るものが $12 \%$ むあ ることを示している.これによって, 原料乳がいかに污 染されているかがわかるであうう。

第 1 表 原料乳の細菌数検查成績（1cc当たり万）

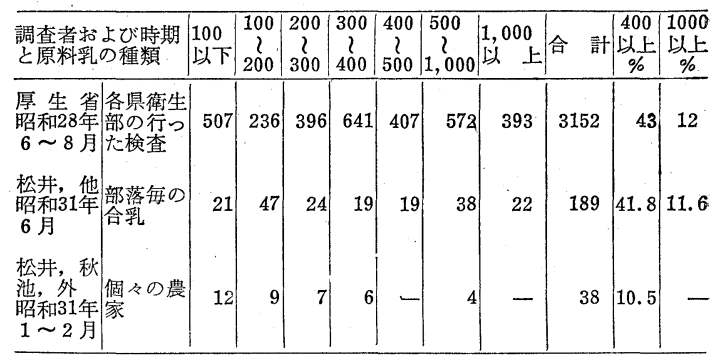

また深田ら4)が北海道札幌地区・計根別地区・釧路地 区で1955年 7 月に行なった個々の農家の生産乳の調査成 績によると，1cc中の細菌数400万以上のものがかなり多 い. 松井ら5) が1955年飞東京都内に搬入される原料乳を 生産部落別に現地集乳所で検査した成績でも，1cc中400 万以上のものが $41.7 \% ， 1,000$ 万以上のものが $11.6 \%$ を 示し, 厚生省の全国調查成績とょく一致している.また 同年, 東京都衛生局6) が調查した成績（第 2 表）による と，年間平均で 1cc中 400 万以上のものが $30 \%$ 占めて 和り, 乳質が最も悪いと思われる 7 月, 8 月, 9 月の時 期についてみると，50〜55\%という高率になっている。 また，比較的乳質がよいと思われる冬季探いても，7 〜10\%近い規格外品がみられる. これは, 松井ら5)が 1956 年 1 月から 2 月にかけて調查した際に得た $1 \mathrm{cc}$ 中 400 万をこえるものが 38 例中 4 例, すなわち $10 \%$ を占め ているという成績とも一致している.

1956年度の成績については, まだ全部の集計が終って いないので，一部の資料7)をあげて概観してみょう.

都下南多摩・津久井画酪農生産の原料乳の工場集荷時 飞和沙る検查成績（第 3 表）を見ると, 生産地と工場と が距離的飞近いためか，かなり成績がよいように思觉る が，それでも $7 \sim 9$ 月ごろのものは，やはり $40 〜 55 \%$ と 
第 2 表 東京都に和ける 1955 年度原料乳検査成績（ミルクプラント集乳時）

\begin{tabular}{|c|c|c|c|c|c|c|c|c|c|c|c|c|c|c|c|}
\hline \multirow{2}{*}{ 種類 - } & 月 & 別 & 1 & 2 & 3 & 4 & 5 & 6 & 7 & 8 & 9 & 10 & 11 & 12 & 計 \\
\hline & 体 & 数 & 831 & 882 & 881 & 863 & 870 & 842 & 834 & 835 & 312 & 789 & 769 & 794 & 10,002 \\
\hline \multirow{4}{*}{ 原乳 } & 規 格 外 数 & 件 \% & $\begin{array}{r}73 \\
9\end{array}$ & $\begin{array}{r}71 \\
8\end{array}$ & $\begin{array}{r}111 \\
13\end{array}$ & $\begin{array}{r}239 \\
28\end{array}$ & $\begin{array}{r}286 \\
33\end{array}$ & $\begin{array}{r}415 \\
49\end{array}$ & $\begin{array}{r}445 \\
53\end{array}$ & $\begin{array}{r}423 \\
51\end{array}$ & $\begin{array}{r}455 \\
56\end{array}$ & $\begin{array}{r}399 \\
51\end{array}$ & $\begin{array}{r}110 \\
14\end{array}$ & $\begin{array}{r}59 \\
7\end{array}$ & $\begin{array}{r}3,086 \\
31 .\end{array}$ \\
\hline & 酸度規格外 & 件 $\%$ & $\begin{array}{r}13 \\
2\end{array}$ & $\begin{array}{r}10 \\
1\end{array}$ & $\begin{array}{r}10 \\
1\end{array}$ & $\begin{array}{r}27 \\
3\end{array}$ & $\begin{array}{r}23 \\
3\end{array}$ & $\begin{array}{r}37 \\
4\end{array}$ & $\begin{array}{r}43 \\
5\end{array}$ & $\begin{array}{r}40 \\
5\end{array}$ & $\begin{array}{r}44 \\
5\end{array}$ & $\begin{array}{r}57 \\
7\end{array}$ & $\begin{array}{r}19 \\
2\end{array}$ & $\begin{array}{r}10 \\
1\end{array}$ & $\begin{array}{r}333 \\
3\end{array}$ \\
\hline & 細菌数規格外 & 件 $\%$ & $\begin{array}{r}63 \\
8\end{array}$ & $\begin{array}{r}64 \\
7\end{array}$ & $\begin{array}{r}104 \\
12\end{array}$ & $\begin{array}{r}220 \\
25\end{array}$ & $\begin{array}{r}279 \\
32\end{array}$ & $\begin{array}{r}412 \\
49\end{array}$ & $\begin{array}{r}441 \\
53\end{array}$ & $\begin{array}{r}414 \\
50\end{array}$ & $\begin{array}{r}449 \\
55\end{array}$ & $\begin{array}{r}390 \\
49\end{array}$ & $\begin{array}{l}93 \\
13\end{array}$ & $\begin{array}{r}50 \\
6\end{array}$ & $\begin{array}{r}2,979 \\
30\end{array}$ \\
\hline & 脂肪 $30 \%$ 以下 & 件 \% & $\begin{array}{l}80 \\
10\end{array}$ & $\begin{array}{r}83 \\
9\end{array}$ & $\begin{array}{r}78 \\
9\end{array}$ & $\begin{array}{r}112 \\
13\end{array}$ & $\begin{array}{r}102 \\
12\end{array}$ & $\begin{array}{r}118 \\
14\end{array}$ & $\begin{array}{r}117 \\
14\end{array}$ & $\begin{array}{r}73 \\
9\end{array}$ & $\begin{array}{r}75 \\
9\end{array}$ & $\begin{array}{l}78 \\
10\end{array}$ & $\begin{array}{r}59 \\
8\end{array}$ & $\begin{array}{r}41 \\
5\end{array}$ & $\begin{array}{r}1,016 \\
10\end{array}$ \\
\hline
\end{tabular}

第 3 表 1956年度都下南多摩・津久井地区の 原料乳検査成績

\begin{tabular}{|c|c|c|c|c|c|c|c|c|c|c|c|c|c|c|}
\hline \multicolumn{2}{|c|}{ 月 別 } & 1 & 2 & 3 & 4 & 5 & 6 & 7 & 8 & 9 & 10 & 11 & 12 & 計 \\
\hline \multicolumn{2}{|c|}{ 検 体 数 } & 94 & 97 & 204 & 102 & 102 & 104 & 78 & 58 & 79 & 88 & 93 & & 1137 \\
\hline 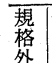 & 件数 & $\begin{array}{r}3 \\
3.1\end{array}$ & $\begin{array}{r}3 \\
3.1\end{array}$ & $\begin{array}{r}5 \\
2.4\end{array}$ & $\begin{array}{r}2 \\
1.9 \\
18\end{array}$ & $\begin{array}{r}20 \\
18.6\end{array}$ & \begin{tabular}{r|r}
8 \\
7.65
\end{tabular} & $\begin{array}{r}43 \\
55.13\end{array}$ & \begin{tabular}{r|}
23 \\
39.7
\end{tabular} & $\begin{array}{r}41 \\
1.8\end{array}$ & $\begin{array}{l}22 \\
25\end{array}$ & \begin{tabular}{l|l}
0 \\
0
\end{tabular} & \begin{tabular}{l|l}
0 & \\
0 &
\end{tabular} & $\begin{array}{r}170 \\
15\end{array}$ \\
\hline
\end{tabular}

第 4 表 都内 S工場に括注る1956年度原料乳 検査成績

\begin{tabular}{c|c|c|c|c|c|c|c|c|c|c|c|c|c}
\hline 月 別 & 1 & 2 & 3 & 4 & 5 & 6 & 7 & 8 & 9 & 10 & 11 & 12 & 計 \\
\hline 検 査 数 & 27 & 25 & 176 & 103 & 106 & 109 & 113 & 61 & 102 & 107 & 105 & 70 & 1003
\end{tabular}

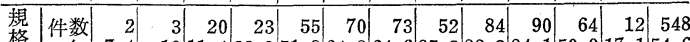

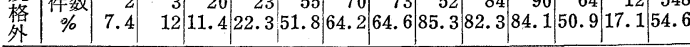
注: 原料乳の入荷先は東京, 神奈川, 千葉, 埼玉, 荻城, 栃木, 群馬, 山梨など.

いう規格外率を示している.

都内 S工場の原料乳の検査成績8) (第 4 表)を見ると, ここに集荷された原料乳は，東京都生産のものが $6.2 \%$ 前後で, 他はすべて神奈川・千葉・埼玉・茨城・栃木・ 群馬・長野・岩手・山梨の各県から移入されたものであ るが，5月以降は規格外率が50\%以上を示し，10月拉よ び11月あたりでも 60 ～80\%という驚異的数字を示してい ることがわかる。

都内和将る 1 日平均牛乳処理量は，1955年度の調查 6)では 1,600 石で, 都内で生産される原料乳は 1 日平均 350 石程度である. したがって都内生産高は消費処理量 のわずか $20 \%$ にすぎず， $80 \%$ 関東一円の他県から移入 されている状態で, 原料乳の生産管理が他県依存の形に なっていることは, 原料乳不適格品の多い理由の一つ であるといえよう・

大腸菌群は，原料乳では $100 \%$ 検出されるが，その存 在は，乳製品に打ける場合とはその意義をことにするも のである. しかし搾乳後の取扱い・冷却の不十分によっ て，夏季に 1cc 中 1 万〜 100万という数を示しているも の（松井ら）は，乳質がきわめて亜いものといえよう.

以上，いずれの成績をみても，原料乳の乳質はがいし て不良で，夏季にあってはとくにとの傾向が著しい。一
方，乳牛の乳房炎は，松下ら99) 1954 年 8 月〜1955年 3 月の調査では頭数䍙病率が $19.2 \%$, 吉田10)は40～50\%， 山田111 $39.8 \%$ と、いずれもかなり高い罹病率を示して いること，乙かもその原因菌が Streptococcus, Micrococcus (ブドウ球菌) であり，これらの菌が原料乳から かなり高率に検出されることは，見のがせない事実であ る. 乳房炎については, 公衆衛生の立場のみならず, 原 料乳の品質保持という点からも，多大の関心を持たざる を得ない。

\section{2. 市販飲用乳の品質}

以上のような原料乳から市乳・乳飲料などが作られる わけであるが，これを細菌学的にみた場合，どうなるか を考えてみよう。すず乳の乳質については，これを， プラント処理ビン詰め直後のものと, 販売店に出された 後のものとの二つに分けて孝学る必要がある.なた，都 内に拈ける肘売店のものは, 都内の製品と, 地方で処理 ビン詰めされた製品との 2 種に分けることができる.

\section{a. ビン詰め直後の製品の品質}

1953年 6 月から 8 月にかけて, 厚生省が原乳調査と同 時に実施した全国的調査成績3)(第 5 表)飞よると, 工場 出荷前の製品は, 法定規格 $1 \mathrm{cc}$ 中 5 万以上のものが 24.1 \%を占め, 大腸菌群は $26.8 \%$ が陽性を示している.

第 5 表 市乳 (殺菌乳) の細菌検査成績

（厚生省・1953年 6 月～8 月）

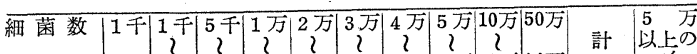

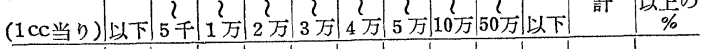
件 数 $\mid$\begin{tabular}{l|l|l|l|l|l|l|l|l|l|l|l}
\hline 79 & 402 & 342 & 450 & 638 & 803 & 720 & 527 & 354 & 246 & 4661 & 24.1 \\
\hline
\end{tabular}

注 : 大晹菌群検查成績は1168件 (C $26.8 \%)$ が陽性.

ところが，1955年に 1 カ年にわたって，都衛生局が都 内のプラントで行なった処理ビン詰め直後の製品の検查

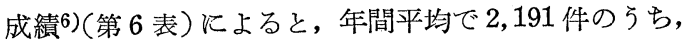

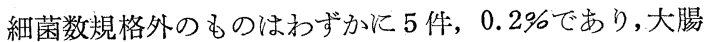
菌群陽性率は $8 \%$ とら,かなりよい成績を示している. 3 月だけについてみると, 総合判定で $12 \%$ 規格外がみら れ, 細菌数で久格するものは 1 件もなく, 大腸菌群につ いては10.5\%が陽性を示しているまた 8 月の成績をみ 
第 6 表 1955年度製品検査成績（プラント出荷前）

\begin{tabular}{l|r|r|r|r|r|r|r|r|r|r|r|r|r|r}
\hline 種 & 月. 別 & 1 & 2 & 3 & 4 & 5 & 6 & 7 & 8 & 9 & 10 & 11 & 12 & 計 \\
\hline 別 & 検 体 数 & 124 & 145 & 135 & 152 & 209 & 206 & 246 & 208 & 192 & 217 & 172 & 182 & 2,192 \\
\hline
\end{tabular}

注 : ( ) 内はパーセントを示す.

ると, 総合判定で16\%規格外がみられるが，細菌数で欠 格するものは $0.96 \%$ と依然低率を示しているのに対し， 大腸菌群は15.4\%という陽性率を示し, 夏季のほうがや はり高い陽性率を示している. しかし全国の成績と比較 して，都下製品はまだよいとい光る。

1956年度の成績については，1例として，前記の都内 $\mathrm{S} 工$ 場に括ける製品の検査成績 ${ }^{12)}$ (第 7 表）をみると， 細菌数規格外は 1 例もなく, 1 cc当たり生菌数平均值も, 年間を通じて 1,000 以下で，きわめて優秀な成績であ る.他の工場に和いても，大体これと同椂な傾向にある とい觉る。

第 7 表 1956 年度都内 S工場に打汗る出荷前製品の 検査成績

\begin{tabular}{l|r|r|r|r|r|r|r|r|r|r|r|r|r}
\hline 月 別 & 1 & 2 & 3 & 4 & 5 & 6 & 7 & 8 & 9 & 10 & 11 & 12 & 計 \\
\hline $\begin{array}{c}\text { 㭘体数 } \\
\text { 幾何 }\end{array}$ & 26 & 24 & 47 & 22 & 16 & 16 & 16 & 16 & 17 & 16 & 16 & 15 & 257 \\
$\begin{array}{c}\text { 平均值 } \\
/ \mathrm{cc}\end{array}$ & $<300$ & $<300$ & 420 & 870 & 1,000 & 1,500 & 510 & 330 & 680 & $<300$ & 1,300 & 1,600 & 660 \\
規格外 & 0 & 0 & 0 & 0 & 0 & 0 & 0 & 0 & 0 & 0 & 0 & 0 & 0 \\
\hline
\end{tabular}

以上, 厚生省の全国調査でも, 東京都に护ける調査で も，原料乳がきわめて悪いわりにしては，製品の乳質が きわめてよいことがわかるのである.これは原料乳と殺 菌乳の規格から考兄て, 当然 $95 \%$ 以上, 場合によっては $99 \%$ 以の殺菌効果を初らった加熱温度と時間の殺菌方 法が行なわれねばならぬことを意味するものである。現 に都内の工場では, Holding system (保持式殺菌法)で は $75^{\circ} \mathrm{C}$ 以上 15 分, H.T.S.T. 法 (高温短時間殺菌法) で

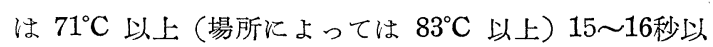
上としているところが実際にあり, 最近では超高温短時 間殺菌を実施しているものもある.

以上の事実をさらに理解するためには, 細菌数と殺菌 方法との関係について述べる必要があると思うので, こ こに一言して扣こう. 現在原料乳の細菌数は, 省令規格 で 1cc 当たり Breed，個体值で 400 万以下となって拉 り, 殺菌乳の細菌数は標準平板培養法で 1cc当たり 5 万 以下と定められている. Breed-個体值400万という数字
を標準平板培養法による生菌数に值すと, 1cc中100万亿 相当する13)。これは $62 \sim 65^{\circ} \mathrm{C}, 30$ 分間の加熱尤る低 温殺菌法では, 殺菌効果を平均 $95 \%$ 内外々みているから である.つまり細菌数 100 万のものが $95 \%$ 殺菌される と，残りの $5 \%$ に相当する 5 万の菌が残るといらことで ある.したがって細菌数が多くなればなるほど, 殺菌温 度々時間が一定である限り, 残存する細菌数が多くなる わけで, このことは, 細菌の死隇が単分子反応の法則 14 〜16) 飞したがう事実からみても，当然の帰結である.ゆ 穴に細菌数の多い原料乳を使って規格に適合する細菌 数の製品を得る場合に，殺菌時間を一定にするとすれ ば, ぞうしても殺菌温度を高くする以外飞方法がないこ とになり，さきに述べたような殺菌方法を採用せざるを 得なくなるわけである。しかしこのような方法で一応細 菌数をへらすこともでき, 同時に病原菌に対する安全性 も高まるわけであるから，これでもよいのではないかと いら考方方も行なわれるわけであるが，これは牛乳衛生 の本質から考学てみて，決して正しい姿とはいえない。

いまかりに原料乳中で, エンテロトキシン産生能を有 するブドウ球菌に自由に繁殖を許した場合を考㝋てみよ う.この場合, 殺菌によって一応細菌そのものをなくす ことはできるが，すで生産された毒素は除去されない から，この核うの危険が残ることとなる。污染度のきわ めて高い原料乳を用いて, しかも細菌学的沈も, 化学的 にも，一応立派な製品ができていることは，かなり高度 の熱処理, あるいはとの他の加工を行なっている.つま り無理をしていることを物語るものであり，このような ことが，ひいては過去に扮ける中毒事故発生の誘因とも 考觉らるのである。

\section{b. 市販品の品質}

都内の販売店に括ける飲用乳を, 都内でビン詰めされ たものと，地方でビン詰めされたものとに分けて考党て 久る. 都内製品では, 1955年われわれが 2 月・4 月・ 8 月 の 3 回にわたって調査した成績6)(第 8 表)によると, 四 季を通じて，肘売店収去のものでは，細菌数で $20 \sim 30 \%$ 前後, 大腸菌群で $30 \sim 40 \%$ がそれぞれ不適格である. 季 節的飞みて，夏がとくに悪いとはい党ず，場合によって は, かえって夏注菌数が少ない例も又られる。これは 原乳の乳質が他の季節よりも悪いところから, 夏には特 別に高度の加熱殺菌を行なっているためとも考㝋られ る. このことは, 都内 $\mathrm{S} 工$ 工場の月別製品検査成績（第 7 表)にもみられる。

以上の成績を, プラント処理ビン詰め直後の製品の成 績と比べてみると，やはり美がみられる。これは，增 菌, あるいは処理後, とくにビン詰め後の污染を考慮す れば，当然と思われ，決して等閑視できない問題であ る.しかし輸送時, あるいは販売店に怙ける取扱いなど について十分注意すれば，原乳の乳質の問題とはことな

\section{日獣会誌 11 (1958)}


第 8 表 1955年度市乳・乳飲料一齊検査成績 (対象：販壳店)

第 1 回 検査 ( 2 月 16 日)

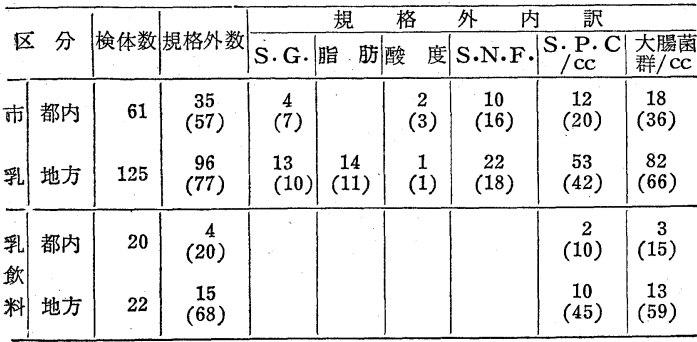

第 2 回 検查（4月 4 日 8 日）

\begin{tabular}{|c|c|c|c|c|c|c|c|c|c|}
\hline 市 & 都内 & 39 & $\begin{array}{c}20 \\
(51)\end{array}$ & & & & & $\begin{array}{c}7 \\
(5)\end{array}$ & $\begin{array}{c}13 \\
(33)\end{array}$ \\
\hline & 地方 & 86 & $\begin{array}{c}70 \\
(81)\end{array}$ & $\frac{1}{(1)}$ & $\begin{array}{c}3 \\
(2)\end{array}$ & $\stackrel{1}{(1)}$ & $\begin{array}{c}18 \\
(21)\end{array}$ & $\begin{array}{c}27 \\
(31)\end{array}$ & $\begin{array}{c}60 \\
(70)\end{array}$ \\
\hline & 都内 & 17 & $\begin{array}{c}6 \\
(27)\end{array}$ & & & & & $\begin{array}{c}2 \\
(7)\end{array}$ & $\begin{array}{c}\mathbf{5} \\
(23)\end{array}$ \\
\hline & 地方 & 1 & $\begin{array}{c}11 \\
(65)\end{array}$ & & & & & $\begin{array}{c}3 \\
(18)\end{array}$ & $\begin{array}{c}10 \\
(59)\end{array}$ \\
\hline
\end{tabular}

第 3 回 検查（8月1日～12日）

\begin{tabular}{|c|c|c|c|c|c|c|c|c|c|}
\hline & 都内 & 276 & $\begin{array}{l}170 \\
(61)\end{array}$ & $\begin{array}{l}10 \\
(4)\end{array}$ & $\begin{array}{c}31 \\
\text { (11) }\end{array}$ & $\begin{array}{c}33 \\
(12)\end{array}$ & $\begin{array}{c}9 \\
(4)\end{array}$ & $\begin{array}{c}79 \\
(29)\end{array}$ & $\begin{array}{l}129 \\
(47)\end{array}$ \\
\hline & 地方 & 163 & $\begin{array}{l}117 \\
(72)\end{array}$ & $\begin{array}{c}13 \\
(8)\end{array}$ & $\begin{array}{c}46 \\
(28)\end{array}$ & $\begin{array}{c}20 \\
(12)\end{array}$ & $\begin{array}{c}8 \\
\text { (5) }\end{array}$ & $\begin{array}{c}57 \\
(35)\end{array}$ & $\begin{array}{l}102 \\
(63)\end{array}$ \\
\hline
\end{tabular}

注 : S. G. =比重 $S \cdot N \cdot F \cdot=$ 無脂乳固形 S.P.C. =細菌数

って, 比較的簡単に解決がつくものと思う.

ところが地方製品についてみると, 乳質は著しく悪 い. 1955年にわれわれが調查したところによると, 細菌 数規格外と大腸菌群陽性は，2月には 125 件中それぞれ 53 件 $(42 \%)$ と82件(66\%)，4月には86件中それぞれ 27 件 $(31 \%)$ と 60 件 $(70 \%) ， 8$ 月には 163 件中それぞれ 57 件 (35\%) と 102 件 (63\%) であった. すなわち30〜40 \%が細菌数規格外， 63〜 70\%が大腸菌群陽性であって， 地方製品と都内製品との間に, 明らかに有意の差が認め られる。

1956年 8 月に行った都内製品执よび地方製品の検査成 績17,18)（第 9 表）をみると, 地方製品は, 都内製品より

第 9 表 1956 年 8 月市販乳の細菌検查成績 (総件数 336件)

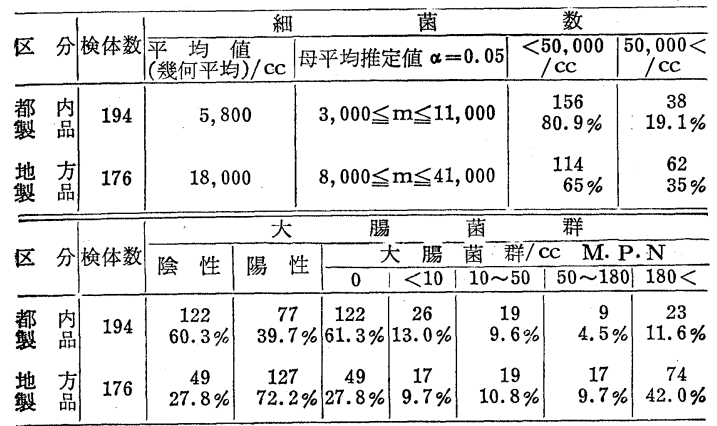

も菌数が多く, 大晹菌群陽性率は都内製品の約 2 倍を示 乙, M. P.N值も, 都内製品よりはるかに高く, 大腸菌 群污染度の高いことを物語っている.1955年，1956年度 の成績でもこのような点がみられるが，これは地方製品 が処理・輸送, おるいは保存・販売など, 取扱の面で十 分でない点があるためと思わ机る。

\section{第10表 1957 年 8 月市販乳の細菌検査成績} (総件数 336 件)

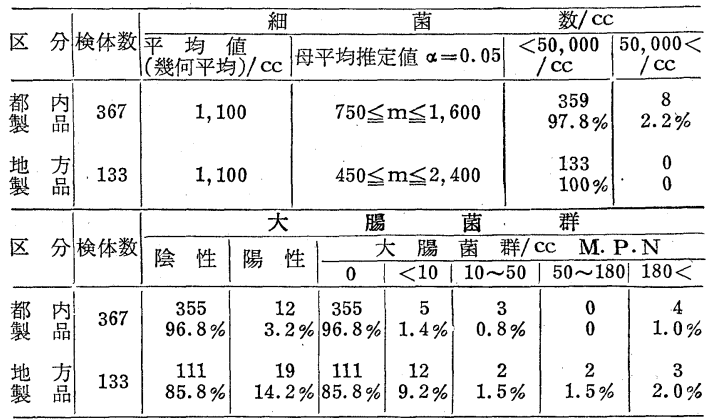

最後に1957年 3 月18日から30日までに10日間実施した 都内の市販飲用乳（市乳・還元牛乳・乳飲料）の検查成 績19) (第10表) を, 細菌学的な面だけについて述べてみ よ5. 細菌数規格外は, 都内製品で 8 件 $(2.2 \%)$ あるの に対し，地方製品では1件もないが，地方製品の大腸菌 群陽性は19件 (14.2\%) で，はるかに高い陽性率を示し ている. 地方製品の菌数がさほど多くないのは, 冬季の 検査でもあるために，当然のことと思われるが，地方製 品を主体としたいわゆる十円牛乳が出現した1955年当初 のころの姿からみれば, 地方製品にあっては格段の進歩 である・

このように地方製品がよい成績を示していることは， 事実，処理などの点で進歩したことにもよるであろう が，あつめられた製品が比較的良質のもので占められて 招り，従来成績の悪かったものが淘汰されて都内に移入 されなくなったことにも，その原因があると思われる。 いずれにしても，この成績は，プラント製造直後の成績 と大差ないように思われる。これが，原乳に対してこれ まで以上に関心がもたれるようになった結果か否かは別 としても，不良品を出さぬようにする努力が払われてい るら光,さらに冬季であるという時期的な点もこれに加 わって，この好成績が出たものと思う。

以上, 東京都に括ける過去数力年の原乳执よび市肘乳 の乳質について，細菌学的に述べてみた。都下では，原 乳も, 製品も, 乳質が漸次向上しつつあるよ5に思われ るが，まだまだ安心はできない，原乳の乳質は，ともす れば憂慮すべき状況に立ちいたる危険性がある．現在で も，かなり無理をして製品が作られていることは，飲用 乳だけでなく，他の乳製品の場合でも事実である.その 
ようなところに牛乳・乳製品による事故発生の危険性が 多分に包蔵されていて, 前に述べた過去の不幸な事故 は, まさに氷山の一角を思わせるものである. したがっ て今後は, むしろ農家などの生産形態を対象とするいわ ゆる搾乳衛生, および原乳の取报・輸送などの面に扔い て,ょり一層の関心と改善への努力を払うべきであろ 3 .

な社東京都以外の地区でつくられるいわゆる地方製品 については, 原乳の取报・処理の面化和いて, 李た都内 に移入される場合は, その輸送・股売などの面に沶い て, より一層の改善を期する必要があると思う．これら のことは, 都内で処理される製品についても当てはまる
事項である。

$$
\text { 参 考 文 献 }
$$

1）嶋田幸治, 春田三佐夫, 外 : 都衛生研報, 13号 (1956)。 2) 阿曾 村千春：日本公衛誌，2 (11号)，(1955)，3）全国酪農協会：酪農の指釬 (1956)．4）浜田, 外：日獣会誌, 9, (2,3号)，(1956). 5) 松井武夫： 畜産の友, 3 (6号), (1956)。一) 東京都獣医衛生課：昭和30年獣医衛生 課業務資料 (1956). 7）8） 未発表.9）松下維浄: 畜産の友，3(4号), (1956). 10）吉田信行：獣医界, $23,6 \sim 13$ (1948); 家揊衛生, 1, 3 9 (1950).

11）山田俊雄: 酪農事情, 10 (7, 8号), (1950). 12) 未発表. 13) 松井武夫：サニテーション, 1 (2号), (1948). 14) MADSEN, and NYMAN, : Z.f. Hyg., 57, 388 (1907). 15) CHICH, : J.Hyg., 8, 92 (1908) ; 10, 237 (1910); 12, 414 (1912). 16) OGINSKY, and UMBREIT, : An Introduction to Bacterial Physiology. W.H. Freeman \& comp. Inc. (1954). 17) 東京都獣医薇生課：昭 和32年獣医葦生課業務資料（1957），18）19）未発表.

Escherichia coli 7:7L:4 によると思われる集団食中毒例について* 河島 俊一**渡辺昭 宣**

わが国に和沙る食中毒の発生は, 厚生省の統計資料1) 飞よっても明らかなごとく, 毎年約 1,300 件, 患者数 23 , 000人で，そのうち死者は $200 〜 300$ 人を数兄られている.

しかし，これら食中毒の原因食品の推定はかなり正確 で, 食中毒例の $80 \%$ 以上が判明せられているが, 病因物 質の検索には多くの未解決な問題があって, 検查の上に 多くの困難が伴い, 食中毒発生件数の約 $7 \sim 8$ 割が不詳 となっている状態である.

また病因物質の判明したもののうち約 $80 \%$ が細菌性食 中毒であるが，とくに最近は赤菽様症状を呈する集団下 峲症が多く, その多くは病原性大腸菌によるものである ことが明らかにされている.

今回われわれの報告する集団食中毒は, 昭和 30 年 7 月 に集団給食を行っている埼玉県東松山市にある某工場に おいて発生したものである, 下淑, 嘔吐, 腹痛, 発熱を 主訴とする集団食中毒で, 細菌学的検索の結果, 多くの
患者より Escherichia coli 7：7L：4 を分離し得たの で, 本食中毒例は該菌関連性をるつ食中毒と推定しし た. 現在まで報告せられている, 病原性大腸菌と呼ば れるむの以外の大晹菌による集団食中毒例として, ここ 法報告する。

\section{I. 臨床症状扎よび疫学的調査}

昭和 30 年 7 月 23 日埼玉県東松山市内の某工場に和い て, 全職員中 (375名), 寮生の 260 名のうちから食中毒 症状を呈し, 久勤しているとの届出があった。

寮生の給食人員は 255 名 (5 名恃寄宿だけ) で発病者 は 191名 (男11名, 女180名), 健康者64名であった.

臨床症状は患者 191 名中, とくに重症患者は 3 名で, 水様性下痢便10数回, 嘔吐, 腹痛が主徵で, 発熱は 38.5 〜39. $1^{\circ} \mathrm{C}$ を記録し，脈搏は72 92を測定した. 大部分の 患者は第 1 表に示すごとくで, 潜伏期は 10〜15 時間が 112 名で過半数を占めている.

1 表臨床症状特よび摂食状況

\begin{tabular}{|c|c|c|c|c|c|c|c|c|c|c|c|c|c|c|c|c|c|c|c|c|c|c|c|}
\hline \multirow{3}{*}{ 潜伏時間 } & 患 & \multicolumn{14}{|c|}{ 症 } & \multicolumn{8}{|c|}{22 日 摄 食 食 品 } \\
\hline & 考 & & & & & & & & & 服症 & & & & | 重色佖 & & 朝 & 食 & 昼 & 食 | & 夕 & & 食 & れも \\
\hline & 者 & 下 痢 & 熱 & 嘔 & 悪感 & 痛 & 煘忿 & 麻瘦 & 発疮 & 状 & 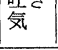 & 頭痛 & 戦樫 & 董空使 & 脱力感 & 米飯 & 嘫汁 & 米飯 & 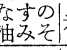 & 米翎 & $\mid \begin{array}{rl}\mathrm{F}^{2} & 7 \\
\mathrm{Z}\end{array}$ & $\begin{array}{l}\text { なすす } \\
\text { 漬 }\end{array}$ & 几水 \\
\hline $0 \sim 5$ 時間 & 5 & 5 & 2 & 1 & 0 & 5 & 4 & 0 & 0 & 2 & 2 & 3 & 1 & 0 & 3 & 4 & 4 & 5 & 5 & 5 & 5 & 4 . & 3 \\
\hline $5 \sim 10$ 時間 & 64 & 64 & 25 & 20 & 21 & 60 & 48 & 1 & 0 & 21 & 24 & 47 & 11 & 13 & 46 & 63 & 63 & 64 & 63 & 64 & 64 & 63 & 48 \\
\hline $10 \sim 15$ 時間 & 112 & 111 & 29 & 15 & 37 & 103 & 75 & 12 & 7 & 21 & 37 & 80 & 13 & 39 & 68 & 108 & 107 & 110 & 110 & 110 & 110 & 107 & 76 \\
\hline 15 18時間 & 2 & 2 & 1 & 1 & 0 & 1 & 1 & 0 & 0 & 0 & 1 & 1 & 0 & 1 & 2 & 2 & 2 & 2 & 2 & 2 & 2 & 2 & 2 \\
\hline 不 明 & 8 & 7 & 1 & 1 & 0 & 5 & 4 & 0 & 0 & 0 & 1 & 3 & 2 & 1 & 2 & 8 & 8 & 8 & 8 & 8 & 8 & 3 & 5 \\
\hline 計 & 191 & 189 & 58 & 38 & 58 & 174 & 132 & 13 & 7 & 44 & 65 & 134 & 27 & 54 & 121 & 185 & 184 & 189 & 188 & 189 & \begin{tabular}{l|l|}
9 & 189 \\
\end{tabular} & 179 & 134 \\
\hline 㣁 & & $\begin{array}{l}\text { 水 様便 } \\
5 \sim 10 \text { 回 }\end{array}$ & $\mid \begin{array}{l}38^{\circ} \sim \\
39.5^{\circ}\end{array}$ & 5 7回 & & $\begin{array}{l}\text { 胃部 痛 } 2 / 3 \\
\text { 腹部痛 } 1 / 3\end{array}$ & & 手 & & 充血 & & $\begin{array}{l}\text { 前頭 } \\
\text { 部 }\end{array}$ & & & & & & & & & & & \\
\hline
\end{tabular}

* 本論文は, 1957 年10月第12回日本公衆衛生学会総会に捛いて発表. *** 埼玉県衛生研究所

日獣会誌 11 (1958) 